\title{
Late-onset Post-lasik Ectasia with no Apparent Risk Factor except Eye Rubbing: A Case Report and Literature Review
}

\author{
1,2Adel Barbara, ${ }^{3}$ Ramez Barbara
}

\begin{abstract}
Post-lasik ectasia is the most feared complication following lasik, occurring in majority of cases within 1 year of surgery. Furthermore, it is reported many years after surgery. In this case report, we describe and analyze a post-lasik ectasia case in one eye which was diagnosed after 11 years without any risk factor or apparent reason except eye rubbing.
\end{abstract}

Keywords: Corneal biomechanics, Eye rubbing, Flap thickness, Keratoconus, Keratoectasia, Lasik, Post-lasik ectasia, Residual stromal bed.

How to cite this article: Barbara A, Barbara R. Late-onset Post-lasik Ectasia with no Apparent Risk Factor except Eye Rubbing: A Case Report and Literature Review. Int J Kerat Ect Cor Dis 2016;5(2):85-91.

\section{Source of support: Nil}

Conflict of interest: None

\section{INTRODUCTION}

Corneal ectasia is the most feared complication after laser in situ keratomileusis (lasik) surgery. It was first reported in 1998 by Seiler and Quurke ${ }^{1}$ in a case of forme fruste keratoconus. The visual rehabilitation of these patients, the irregular astigmatism, the need for contact lenses, or even corneal transplantation make the prevention of this complication imperative in refractive surgery candidates. The proved value of collagen corneal crosslinking (CXL) in arresting the progression of the ectasia ${ }^{2}$ makes early diagnosis crucial to prevent deterioration of vision. In this case report, we describe a case of post-lasik ectasia in the left eye (LE) which was diagnosed 11 years after surgery without any preoperative risk factor. Intensive eye rubbing was reported by the patient only in one of his two operated eyes, i.e., the LE.

\footnotetext{
1,2Medical Director

${ }^{1}$ The National Center for the Treatment of Keratoconus, Haifa Israel

${ }^{2}$ IVISION Refractive Surgery Center, Haifa, Israel

${ }^{3}$ Ophthalmologist at Southampton Eye Unit, Southampton General Hospital, Southampton, UK

Corresponding Author: Adel Barbara, Medical Director, The National Center for the Treatment of Keratoconus, Haifa, Israel e-mail: Adelbarbara@yahoo.cpm
}

\section{CASE REPORT}

A 44-year-old male underwent lasik in our medical center on July 3, 2005 by an external doctor who performs surgery for his patients in our medical center, IVISION Refractive Surgery Center, since he suffered from low myopia and astigmatism. The anterior segment, the lens, the fundus, and the intraocular pressure were normal in both eyes, as reported by his doctor.

The corneal topography by TOPCON KR 700 P topographer (TOPCON, Japan) was normal in both eyes (Fig. 1); the corneal topography (Figs 2 to 3) performed by the Orbscan II (Bausch \& Lomb, USA) was normal too in both eyes; and no signs of forme fruste keratoconus were noted. The corneal thickness was $631 \mu \mathrm{m}$ in the RE and $621 \mu \mathrm{m}$ in the LE as measured by the Orbscan II.

The corrected refraction was -2.75 sphere $(S)=-2.64$ cylinder (CYL) at $24^{\circ}$ in the RE, $-2.02 \mathrm{~S}=-0.27 \mathrm{CYL}$ at $106^{\circ}$. The total ablation depth was 55 and $37 \mu \mathrm{m}$ in the $\mathrm{RE}$ and LE respectively. The laser was performed by VISX S4 customized ablation with iris registration (VISX, California, USA).

The flap thickness done by the Hansatome (Bausch \& Lomb, USA) was $160 \mu \mathrm{m}$ in both eyes. No intra- or postoperative complications were noted. Six months postoperatively the TOPCON KR 700 topography was normal with central flattening of the cornea (Fig. 4). The red area in the LE is an artifact (Fig. 5).

Almost 11 years after surgery he was referred to us by an ophthalmologist because of deterioration of his visual acuity (VA) in his LE which started 2 years prior to his

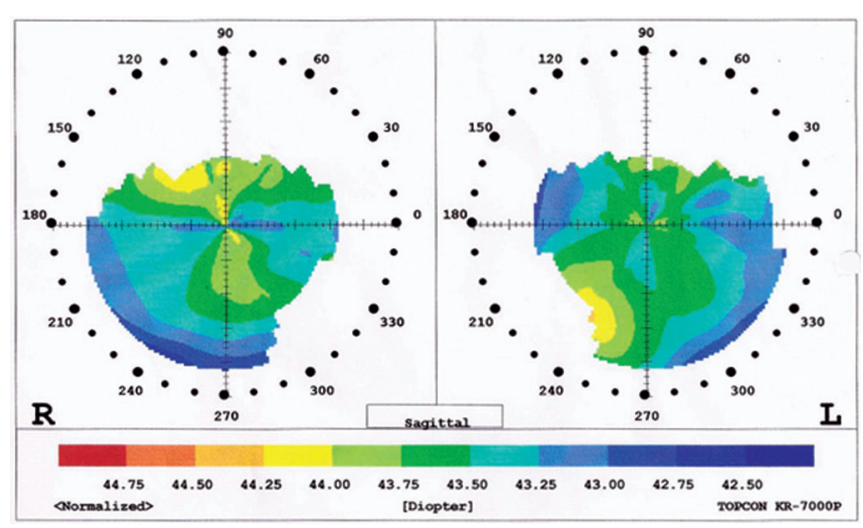

Fig. 1 


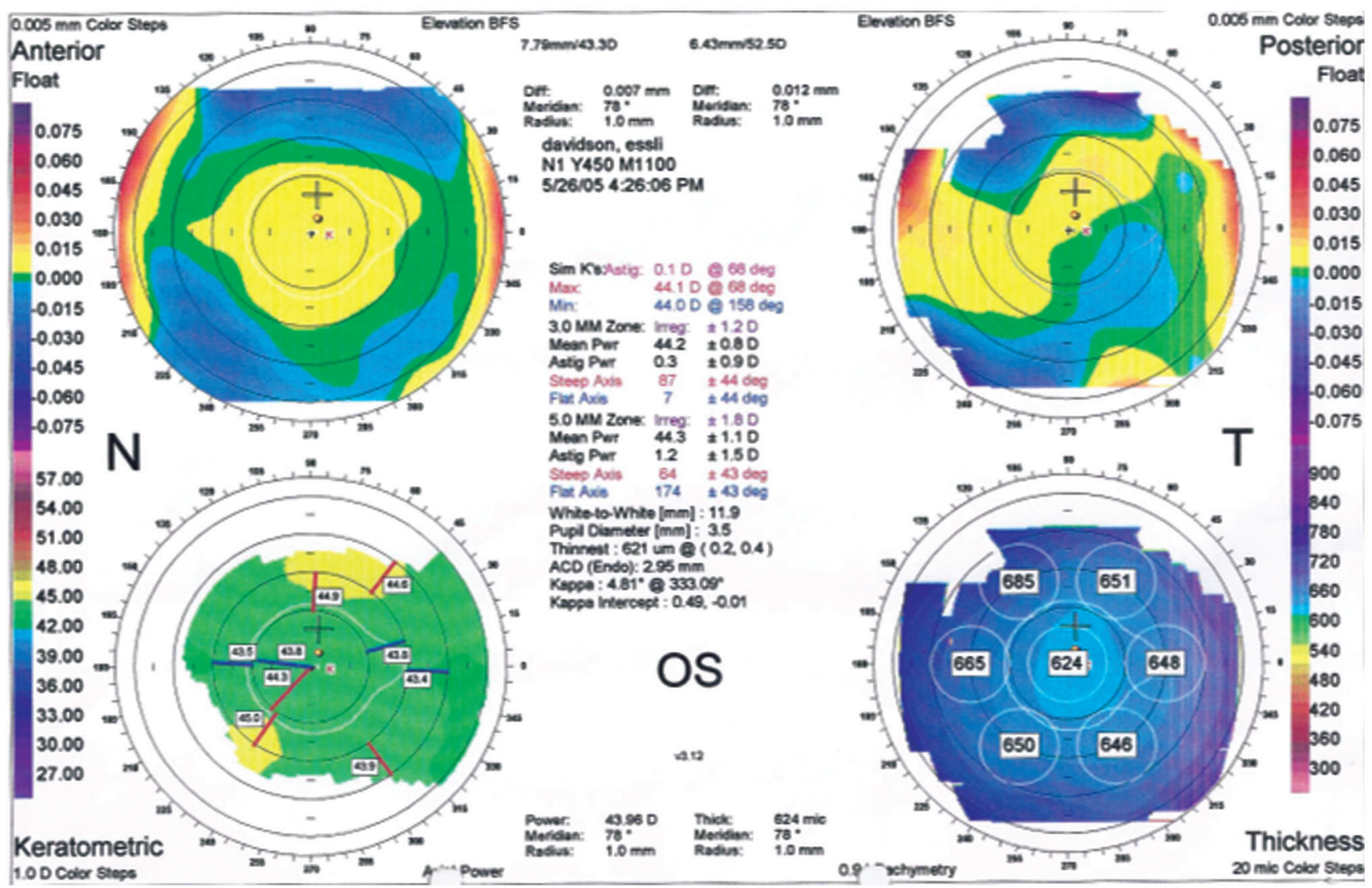

Fig. 2

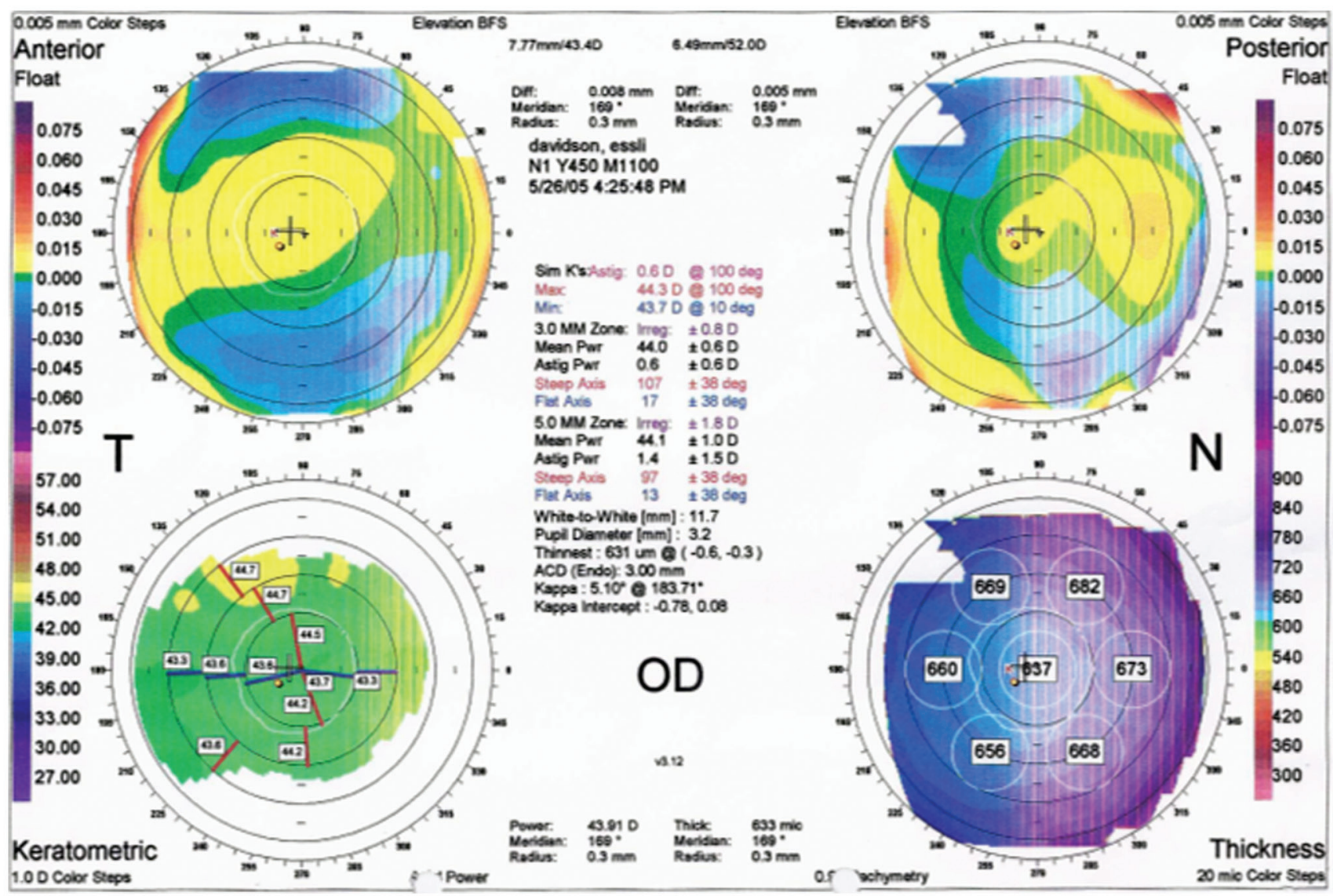

Fig. 3 


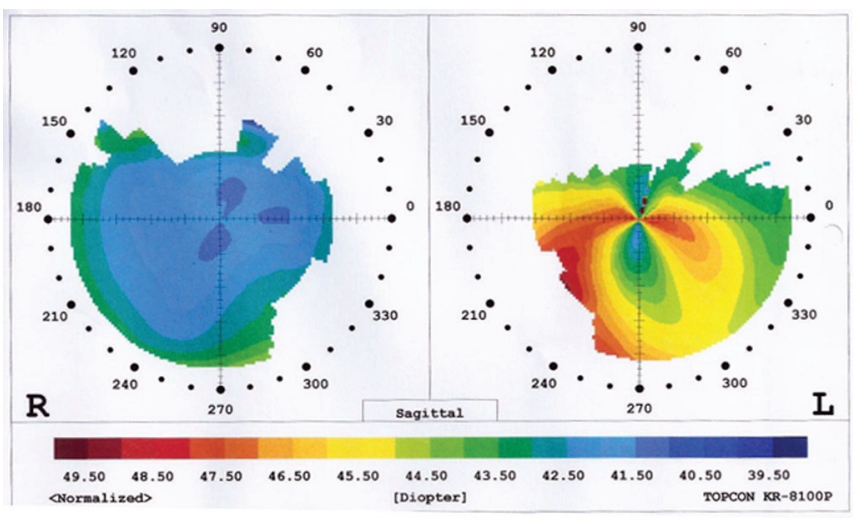

Fig. 4

examination, and on suspicion of post-lasik ectasia, he was examined on June 28, 2016.

His uncorrected visual acuity (UCVA) was 6/6 in the $\mathrm{RE}, 6 / 18$ in the LE, his best spectacle corrected visual acuity (BSCVA) was 6/7 in the LE, and the refraction was in the LE: Plano $=-3.5 \mathrm{CYL}$ at $80^{\circ}$. The anterior segment of both eyes was normal, the lens clear in both eyes, and the fundus examination was normal in both eyes.

The TOPCON KR 700 topography (Fig. 4) shows an ectasia in his LE and a normal post-lasik topography in the RE; the same appears (Figs 6A and B) in the TMS 5 topography (TOMEY, Japan) and the CASIA II topography (TOMEY, Japan) (Figs 7A and B).

The corneal thickness in the RE as measured by the CASIA II is $613 \mu \mathrm{m}$ in the RE and $595 \mu \mathrm{m}$ in the LE, and $611 \mu \mathrm{m}$ in the RE and $578 \mu \mathrm{m}$ in the LE as measured by the TMS 5.

The flap thickness as measured by the CASIA II does not exceed $220 \mu \mathrm{m}$ in both eyes (Figs 8A and B).

He reported vigorous eye rubbing 3 years earlier only in the LE for almost 3 months 3 years before my examination, 1 year prior to the deterioration of his vision in the LE.

We suggested to the patient the following treatments:

- Partial correction of his VA by glasses, or full correction by contact lens and a follow-up; CXL to be performed in case of further deterioration of his VA.

- Photorefractive keratectomy (PRK) combined with CXL.

- Intrastromal corneal ring (ISCR) and follow-up; CXL to be performed in case of further deterioration of his VA.

\section{DISCUSSION}

Since first reported by Seiler and Quurke, ${ }^{1}$ many papers reported on post-lasik ectasia. ${ }^{3-11}$ Randleman et $\mathrm{al}^{3}$ reported in 2003 on 43 eyes with average time of ectasia onset at 16.3 months (1-45 months) postsurgery. Randleman et $\mathrm{al}^{4}$ reported in a review on risk factors

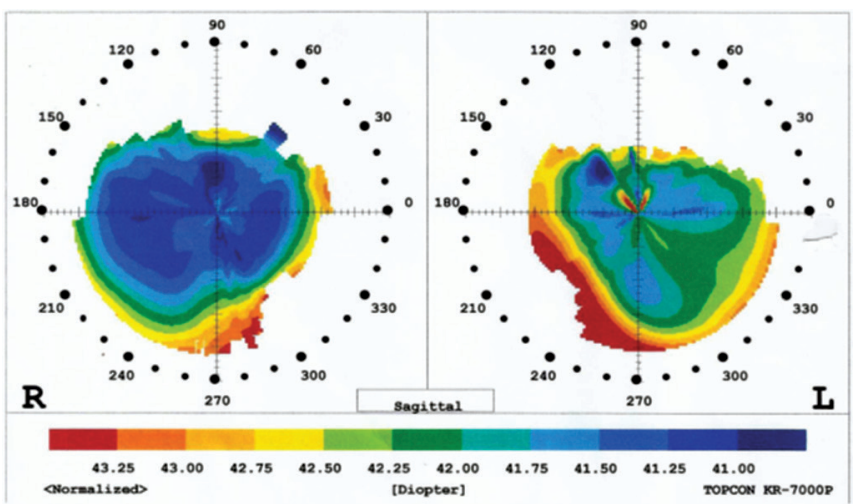

Fig. 5

for the development of ectasia in 171 ectasia cases; including 158 published and 13 unpublished cases which were evaluated at the authors' institution; 164 post-lasik ectasia and 7 post-PRK ectasia. One-third of cases developed ectasia within 6 months, $50 \%$ of cases by 12 months, and $75 \%$ by 18 months. Average time to the development of ectasia was 15.3 months. ${ }^{4}$ Young age ( $<30$ years) is a risk factor for the development of ectasia, in addition to abnormal topography (forme fruste keratoconus), high myopia, thin cornea, and low residual stromal bed. ${ }^{4}$

Klein et $\mathrm{al}^{5}$ reported on 27 eyes of 25 patients who developed ectasia. Mean time to diagnosis was 14.2 months (3-27 months). Randleman et $\mathrm{al}^{6}$ reported on 50 eyes that had an onset of ectasia less than 3 years post-lasik surgery. Brenner et $\mathrm{al}^{7}$ reported on 96 eyes between 1996 and 2010, of which 72 had mean time to diagnosis of 4.79 years. Said et $\mathrm{al}^{8}$ reported on 29 eyes of 19 patients, with mean time of onset of $57 \pm 24$ months (24-120 months) post-lasik surgery). Spadea et $\mathrm{al}^{9}$ reported on ectasia in $0.57 \%$ of 4,027 eyes at 7 years follow-up. The authors divided patients into two groups according to date of surgery. The time to ectasia onset after lasik was $2.57 \pm 1.04$ (1-4 years) in group 1 and $2.64 \pm 1.29$ (0.5-5 years) in group 2. Pallikaris et $\mathrm{al}^{10}$ reported on 19 eyes of 14 patients of 2,873 operated eyes ( $0.66 \%$ ). The mean follow-up was 16.32 months (6-42 months). Hafezi et $\mathrm{al}^{11}$ reported on five patients who were stable for years post-lasik surgery and only developed ectasia after pregnancy. The authors attributed that to massive increase in estrogen levels. Ectasia was diagnosed in 2 eyes 4 years after lasik, one after 5 years, one after 6 years, and one after 9 years.

The main risk factors are: young age, high myopia, thin corneas, retreatments, and forme fruste keratoconus. ${ }^{12}$

Post-lasik ectasia is under reported. Articles that report on score for the development of post-lasik ectasia are not long enough to elicit long-term onset. Our group published an article on a case series in which ectasia was diagnosed in 3 eyes 6 years post-lasik ( 2 eyes of the same patient), 

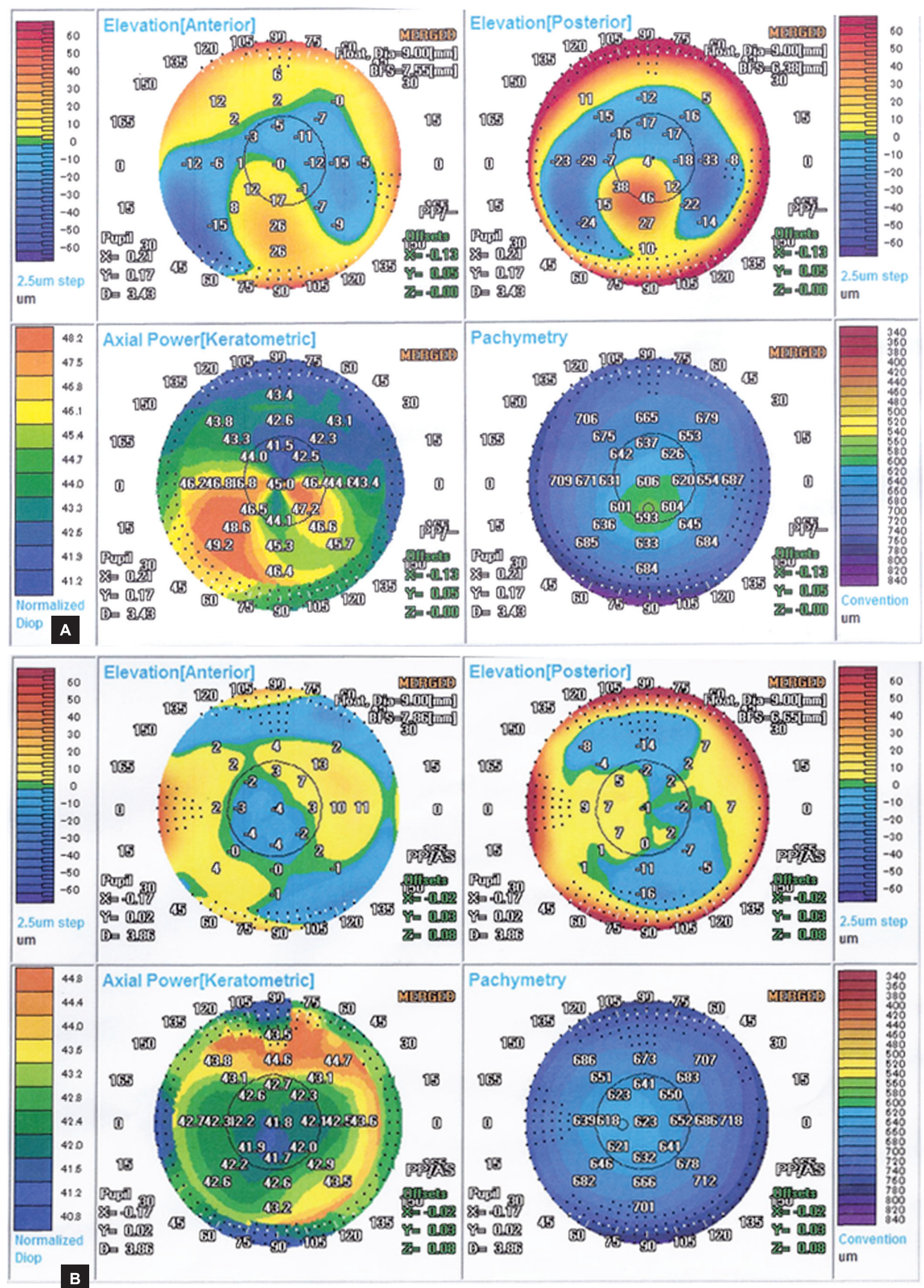

Figs $6 A$ and $B$ 


\begin{tabular}{|c|c|c|c|c|c|c|}
\hline \multicolumn{3}{|l|}{ Keratometric } & \multirow{2}{*}{\multicolumn{2}{|c|}{ Axial Power [Keratometric] }} & \multirow{2}{*}{ Axial Power [Posterior] } & \multirow{2}{*}{$\dot{v}$} \\
\hline $\begin{array}{l}\text { Ks } \\
\text { Kf }\end{array}$ & $\begin{array}{l}47.5 \mathrm{D} \\
43.4 \mathrm{D}\end{array}$ & $\begin{array}{l}179^{\circ} \\
89^{\circ}\end{array}$ & & & & \\
\hline $\begin{array}{l}\text { Kf } \\
\text { CYL }\end{array}$ & $\begin{array}{r}43.4 \mathrm{D} \\
4.1 \mathrm{D}\end{array}$ & & & ass & & 105 \\
\hline AvgK & 45.4 D & & & ass & & os \\
\hline AA $(10 \mathrm{~mm})$ & $92.4 \%$ & & & 475 & & 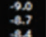 \\
\hline ACCP & 45.3 D & & & ess & & , \\
\hline $\operatorname{Ecc}(9.0 \mathrm{~mm})$ & -0.35 & & & ass & ? & 列 \\
\hline \multicolumn{3}{|l|}{ Posterior } & & as & & \& \\
\hline Ks & $-7.0 \mathrm{D}$ & (i) $3^{\circ}$ & & 2.5 & & $\$ 0$ \\
\hline Kf & $-6.2 \mathrm{D}$ & (i) $93^{\circ}$ & & 2.5 & -. & sit \\
\hline CYL & $0.8 \mathrm{D}$ & & & iss & & ts \\
\hline AvgK & $-6.6 \mathrm{D}$ & & & coss & $2 x$ & 12 \\
\hline AA $(10 \mathrm{~mm})$ & $90.2 \%$ & & & sos & & \\
\hline $\operatorname{Ecc}(9.0 \mathrm{~mm})$ & 0.55 & & & & & \\
\hline \multicolumn{3}{|l|}{ Real } & & & & \\
\hline Ks & $46.1 \mathrm{D}$ & (i) $179^{\circ}$ & Axial Power [Real] & • & Pachymetry & r \\
\hline Kf & $42.3 \mathrm{D}$ & (i) $89^{\circ}$ & & & & \\
\hline CYL & $3.8 \mathrm{D}$ & & & ons & & $\sum_{3,00}^{200}$ \\
\hline AvgK & $44.2 \mathrm{D}$ & & & ws & & $\begin{array}{l}130 \\
100 \\
400\end{array}$ \\
\hline AA $(10 \mathrm{~mm})$ & $90.2 \%$ & & & 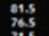 & & $\begin{array}{l}400 \\
400\end{array}$ \\
\hline ACCP & 44.1 D & & & $\begin{array}{ll}\text { ins } \\
\text { ins } \\
\text { its }\end{array}$ & & $\begin{array}{l}400 \\
300 \\
500\end{array}$ \\
\hline \multicolumn{3}{|l|}{ Pachymetry } & & 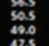 & - & 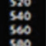 \\
\hline Apex & 612 um & & & ist & & 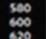 \\
\hline Thinnest & $\begin{array}{l}595 \mathrm{um} \\
(-0.0 \mathrm{~mm} \text {, }\end{array}$ & $-1.1 \mathrm{~mm}$ ) & & $\begin{array}{l}\text { as } \\
\text { sio } \\
\text { ist. } \\
\text { is }\end{array}$ & & 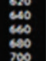 \\
\hline Pupil D & $\begin{array}{l}4.04 \mathrm{~mm} \\
(0.2 \mathrm{~mm} \text {, }\end{array}$ & $0.1 \mathrm{~mm}$ ) & & $\begin{array}{l}3130 \\
375 \\
340 \\
340 \\
190\end{array}$ & 280 & 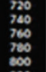 \\
\hline ACD [Endo.] & $3.13 \mathrm{~mm}$ & & & 14 & & 200 \\
\hline ESI & $29 \%$ & & & & 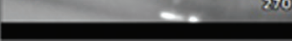 & \\
\hline
\end{tabular}

\section{A}

Keratometric

Ks

Kf

AvgK

AA $(10 \mathrm{~mm})$

ACCP

Ecc $(9.0 \mathrm{~mm})$

Posterior

\begin{tabular}{|l|r|l|}
\hline Keratometric| & & \\
\hline Ks & $43.0 \mathrm{D}$ & $100^{\circ}$ \\
\hline Kf & $42.1 \mathrm{D}$ & $10^{\circ}$ \\
\hline CYL & $0.8 \mathrm{D}$ & \\
\hline AvgK & $42.6 \mathrm{D}$ & \\
\hline AA $(10 \mathrm{~mm})$ & $90.7 \%$ & \\
\hline ACCP & $42.6 \mathrm{D}$ & \\
\hline Ecc $(9.0 \mathrm{~mm})$ & -0.44 & \\
\hline Posterior & & \\
\hline Ks & $-6.1 \mathrm{D}$ & $107^{\circ}$ \\
\hline Kf & $-5.9 \mathrm{D}$ & $17^{\circ}$ \\
\hline CYL & $0.2 \mathrm{D}$ & \\
\hline AvgK & $-6.0 \mathrm{D}$ & \\
\hline AA $(10 \mathrm{~mm})$ & $87.9 \%$ & \\
\hline Ecc $(9.0 \mathrm{~mm})$ & 0.36 & \\
\hline
\end{tabular}

Real

Ks

CYL

AvgK

AA $(10 \mathrm{~mm})$

ACCP

\section{Pachymetry}

Apex 618 um

Thinnest

\begin{tabular}{|l|l|}
\hline & $(-1.1 \mathrm{~mm}, \quad 0.2 \mathrm{~mm})$ \\
\hline Pupil D & $\left.\begin{array}{l}4.26 \mathrm{~mm} \\
(-0.5 \mathrm{~mm},\end{array} 0.0 \mathrm{~mm}\right)$
\end{tabular}

ACD [Endo.] $3.05 \mathrm{~mm}$

ESI

B

$41.1 \mathrm{D} 8^{\circ}$

41.50

$87.9 \%$

$41.5 \mathrm{D}$
Axial Power [Keratometric]

Axial Power [Posterior]

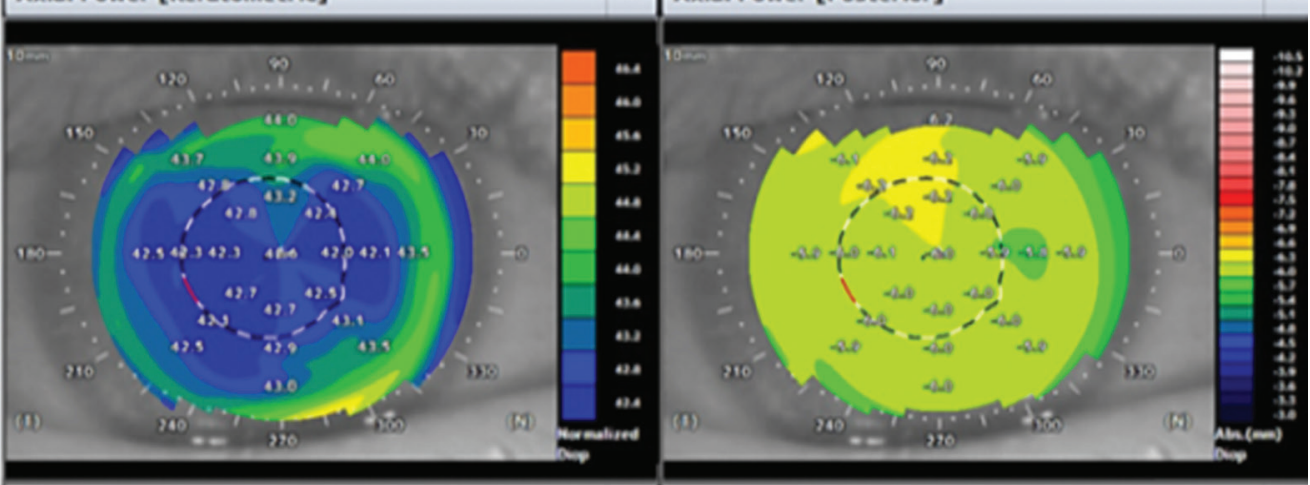

\begin{tabular}{|l|l|l|}
\hline Axial Power [Real] & Pachymetry \\
\hline
\end{tabular}
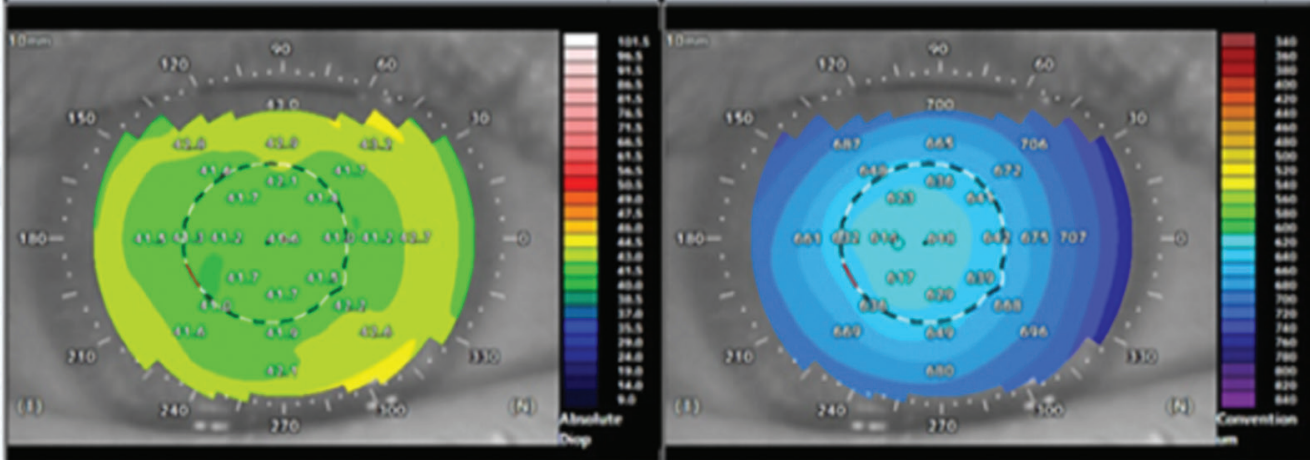

Figs $7 \mathrm{~A}$ and $\mathrm{B}$ 

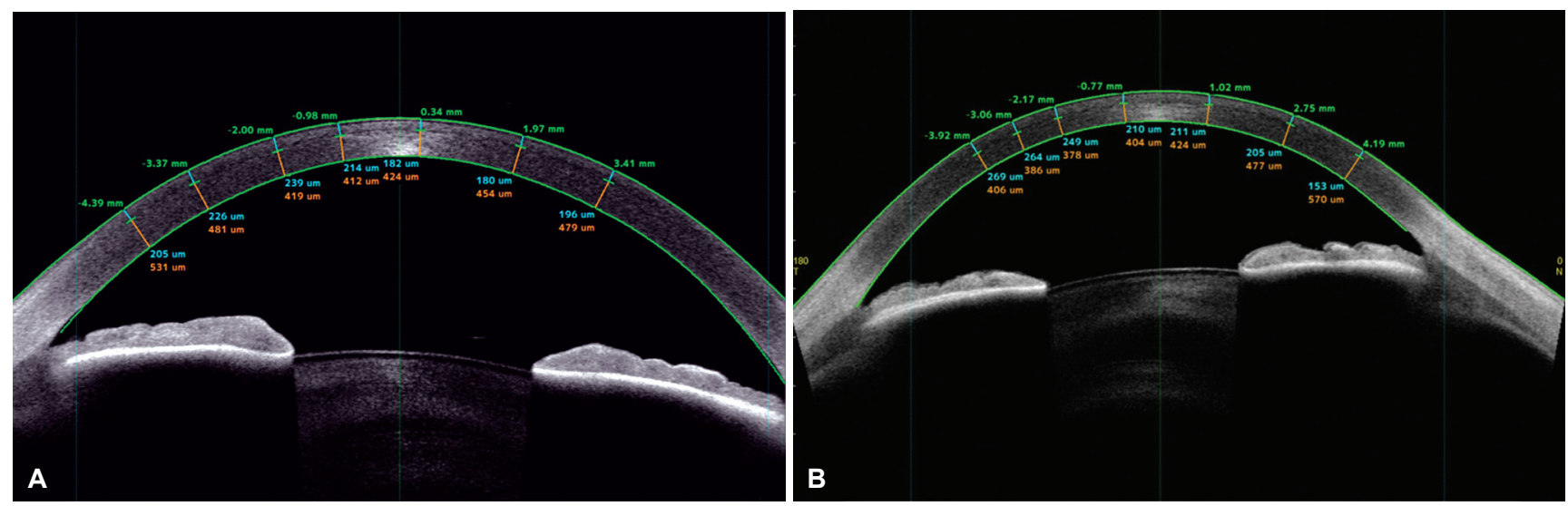

Figs $8 A$ and $B$

4 eyes 8 years postsurgery, 2 eyes 9 years postsurgery, and 2 eyes 11 years after lasik in the same patient. ${ }^{13}$ The onset of ectasia may be delayed years postoperatively.

\section{Eye Rubbing and Ectasia}

Eye rubbing may be the reason of keratoconus development and progression. ${ }^{14,15}$ Avni-Zauberman and Rootman ${ }^{16}$ reported on a case of post-lasik ectasia associated with sleep apnea and floppy eye lid syndrome without any risk factor and also in this case mechanical trauma was suggested as one of the mechanisms that caused the ectasia.

Comaish et al reported in an analysis on the mechanisms of post-lasik ectasia on a case of post-lasik ectasia, which developed because of eye rubbing without any other risk factor. ${ }^{17}$

While patients suffering from keratoconus may use contact lenses to improve their best-corrected visual acuity (BCVA), post-lasik ectasia patients find it more difficult to use contact lenses; ectasia patients underwent lasik surgery to "free" them from spectacles and contact lenses. Prior to surgery they could see with glasses, but once ectasia develops their VA improves with glasses only partially. Ectasia patients are more demanding than patients suffering from keratoconus.

Intrastromal corneal rings improve UCVA and BSCVA in keratoconus and post-lasik ectasia patients. ${ }^{18-21}$ Intrastromal corneal rings reduce astigmatism and keratometry readings and stabilize the cornea.

The introduction of collagen CXL by the Dressden Group $^{22}$ opened new frontiers for arresting keratoconus progression. The treatment flattens the cornea, reduces astigmatism and in two-thirds of patients improves the UCVA and BSCVA. Collagen cross-linking is effective in arresting the progression of post-lasik ectasia; ${ }^{2,23,24}$ therefore, it is crucial to recognize post-lasik ectasia early in the course to arrest progression.

Photorefractive keratectomy with CXL performed sequentially on the same day ${ }^{25}$ was reported as effective in stabilizing the cornea of patients suffering from postlasik ectasia and improved their VA.

This is why ISCR, CXL, and PRK were given to this patient as optional treatments.

\section{What is Particular about this Case?}

- No one of the risk factors above mentioned existed in this case. The patient age at the time of operation was 44 years, he had low myopia, thick cornea, and normal corneal topography.

- The flap thickness and the residual bed could be measured in this case by optical coherence tomography with the CASIA II and by this an unexpected thick flap or deep laser ablations could be excluded.

- Intensive eye rubbing reported by the patient is a possible cause of the ectasia.

This case as our above-mentioned case series poses some important questions with regard to lasik patients' follow-up: Is yearly examination recommended up to 10-year duration? Do we have to warn our already operated persons about the possibility of developing ectasia many years postsurgery, bearing in mind the low percentage of patients who develop ectasia, which might create unnecessary fear and inconvenience to patients and ophthalmologists? Do we have to warn and stress to all post-lasik persons that eye rubbing is absolutely forbidden? These questions are yet to be answered.

\section{CONCLUSION}

Post-lasik ectasia is a known complication of refractive surgery, even many years later. Late onset, although rare, should be kept in mind. Early diagnosis is crucial for management and arresting its progression.

\section{REFERENCES}

1. Seiler T, Quurke AW. Iatrogenic keratectasia after LASIK in a case of forme fruste keratoconus. J Cataract Refract Surg 1998 Jul;24(7):1007-1009. 
2. Vinciguerra P, Camesasca FI, Albè E, Trazza S. Corneal collagen cross-linking for ectasia after excimer laser refractive surgery: 1-year results. J Refract Surg 2010 Jul;26(7): 486-497.

3. Randleman JB, Russell B, Ward MA, Thompson KP, Stulting RD. Risk factors and prognosis for corneal ectasia after LASIK. Ophthalmology 2003 Feb;110(2):267-275.

4. Randleman JB, Woodward M, Lynn MJ, Stulting RD. Risk assessment for ectasia after corneal refractive surgery. Ophthalmology 2008 Jan;115(1):37-50.

5. Klein SR, Epstein RJ, Randleman JB, Stulting RD. Corneal ectasia after laser in situ keratomileusis in patients without apparent preoperative risk factors. Cornea 2006 May;25(4):388-403.

6. Randleman JB, Trattler WB, Stulting RD. Validation of the Ectasia Risk Score System for preoperative laser in situ keratomileusis screening. Am J Ophthalmol 2008 May;145(5): 813-818.

7. Brenner LF, Alió JL, Vega-Estrada A, Baviera J, Beltrán J, Cobo-Soriano R. Clinical grading of post-LASIK ectasia related to visual limitation and predictive factors for vision loss. J Cataract Refract Surg 2012 Oct;38(10):1817-1826.

8. Said A, Hamade IH, Tabbara KF. Late onset corneal ectasia after LASIK surgery. Saudi J Ophthalmol 2011 Jul;25(3): 225-230.

9. Spadea L, Cantera E, Cortes M, Conocchia NE, Stewart CW. Corneal ectasia after myopic laser in situ keratomileusis: a long-term study. Clin Ophthalmol 2012;6:1801-1813.

10. Pallikaris IG, Kymionis GD, Astyrakakis NI. Corneal ectasia induced by laser in situ keratomileusis. J Cataract Refract Surg 2001 Nov;27(11):1796-1802.

11. Hafezi F, Koller T, Derhartunian V, Seiler T. Pregnancy may trigger late onset of keratectasia after LASIK. J Refract Surg 2012 Apr;28(4):242-243.

12. Randleman JB. Evaluating risk factors for ectasia: what is the goal of assessing risk? J Refract Surg 2010 Apr;26(4): 241-250.

13. Barbara R, Abdelaziz L, Pikkel J, Barua A, Garzozi H, Barbara A. Late onset post-Lasik ectasia. Int J Kerat Ect Cor Dis 2012 Sep-Dec;1(3):190-195.
14. Hawkes E, Nanavaty MA. Eye rubbing and keratoconus: a literature review. Int J Kerat Ect Cor Dis 2014 Sep-Dec;3(3): 118-121.

15. Gatinel D. Eye rubbing: a sine qua for keratoconus. Int J Kerat Ect Cor Dis 2016 Jan-Apr:5(1):6-12.

16. Avni-Zauberman N, Rootman DS. Post-LASIK keratoectasia developing with sleep apnea and floppy eyelid syndrome: case report and review of the literature. Int J Kerat Ect Cor Dis 2014 Jan-Apr;3(1):44-46.

17. Comaish IF1, Lawless MA. Progressive post-LASIK keratectasia: biomechanical instability or chronic disease process? J Cataract Refract Surg 2002 Dec;28(12):2206-2213.

18. Tunc Z, Helvacioglu F, Sencan S. Evaluation of intrastromal corneal ring segments for treatment of post-LASIK ectasia patients with a mechanical implantation technique. Indian J Ophthalmol 2011 Nov-Dec;59(6):437-443.

19. Ha CI, Choi SK, Lee DH, Kim JH. The clinical results of intrastromal corneal ring segment implantation using a femtosecond laser in keratectasia. J Korean Ophthalmol Soc 2010 Jan;51(1):1-7.

20. Alió J, Salem T, Artola A, Osman A. Intracorneal rings to correct corneal ectasia after laser in situ keratomileusis. J Cataract Refract Surg 2002 Sep;28(9):1568-1574.

21. Piñero DP, Alio JL. Intracorneal ring segments in ectatic corneal disease - a review. Clin Experiment Ophthalmol 2010 Mar;38(2):154-167.

22. Wollensak G, Spoerl E, Seiler T. Riboflavin/ultraviolet-A induced collagen crosslinking for the treatment of keratoconus. Am J Ophthalmol 2003 May;135(5):620-627.

23. Salgado JP, Khoramnia R, Lohmann CP, von Mohrenfels CW. Corneal collagen crosslinking in post-LASIK keratectasia. Br J Ophthalmol 2011 Apr;95(4):493-497.

24. Suri K, Hammersmith KM, Nagra PK. Corneal collagen cross-linking: ectasia and beyond. Curr Opin Ophthalmol 2012 Jul;23(4):280-287.

25. Kanellopoulos AJ, Binder PS. Management of corneal ectasia after LASIK with combined, same-day, topography-guided partial transepithelial PRK and collagen cross-linking: the Athens protocol. J Refract Surg 2011 May;27(5):323-331. 
